\title{
Factors influencing the productivity of irrigated crops in southern Peru, in relation to prediction by simulation models
}

M. N. Versteeg (Guest, Centre for Agrobiological Research, P.O. Box 14, 6700 AA Wageningen, the Netherlands)

Received 29 January 1985; accepted 31 January 1985

\begin{abstract}
Potential growth of lucerne, potatoes, Rhodes grass and maize in the irrigated desert of southern Peru was determined and important growth-influencing factors were identified for each crop. The data were related to results from simulation models developed in Wageningen.

Key-words: lucerne, potatoes, Rhodes grass, maize, crop growth simulation, potential growth, water utilization, nutrient uptake.

Introduction. Crop yields in irrigated areas in less developed countries are, on average, less than half those in developed countries. The utilization efficiency of the often scarce resource water is thus very low. This is due to the fact that more than half of the irrigation water is not used for crop transpiration but is lost in other ways. By aiming at the highest possible yield per unit irrigated area, these losses can effectively be reduced. Simulation models may assist in setting references for such desirable yield levels.
\end{abstract}

Materials and methods. From 1979 to 1982, an agricultural research project, sponsored by DGIS (the Netherlands), was carried out in the desert plain of San Camilo (S. Peru, $16^{\circ} \mathrm{S}, 71^{\circ} \mathrm{W}$, altitude $1300 \mathrm{~m}$ ). The project was a joint effort of scientists and institutions from the Netherlands, Israel and Peru (Alberda, 1984). Investigations were mainly focussed on lucerne (Medicago sativa), potatoes (Solanum tuberosum), Rhodes grass (Chloris gayana) and maize (Zea mays), representing perennial and annual crops with either the $\mathrm{C}_{3}$ or $\mathrm{C}_{4}$ photosynthetic pathways. To obtain a comparative basis, first growth curves were determined under optimum supply of water and nutrients through periodic harvests. In addition, the aim was to detect rapidly any unusual growth behaviour and to obtain validation data for simulation models. Cumulative uptake of $\mathrm{N}, \mathrm{P}$ and $\mathrm{K}$ was determined and periodic measurements of leaf area index (LAI), specific leaf area (SLA) and light interception by the canopy were made. Special emphasis was placed on lucerne through a crop management experiment, a cutting frequency experiment and additional pot experiments on root development and nitrogen fixation. In addition, photosynthesis measurements on individual plants and artifical lucerne swards in greenhouses were carried out in Wageningen. 
Results. Well-irrigated lucerne produced $27 \mathrm{tha}^{-1}$ of dry matter annually with ten cuttings. Maximum linear growth rates of 125 (winter) to $225 \mathrm{~kg} \mathrm{ha}^{-1} \mathrm{~d}^{-1}$ (summer) could be maintained for only two to three weeks, much shorter than the periods reported from higher latitudes (e.g. Woodward \& Sheehy, 1979). After that period a dramatic decrease or even a standstill in above-ground growth was measured, despite a still green canopy and no indication for a decline in assimilatory capacity. Experimental evidence suggested that this was largely due to an assimilate partitioning that favours the root system, which at low cutting frequencies leads to the build-up of a large mass of roots (up to $25 \mathrm{t} \mathrm{ha}^{-1}$ ). Although $\mathrm{N}$ fixation was estimated at about $700 \mathrm{~kg} \mathrm{ha}^{-1} \mathrm{yr}^{-1}$, high $\mathrm{N}$ fertilizer application resulted consistently in 8-13\% higher forage yields, probably due to lower respiration losses. Frequent cutting caused declined plant density, mainly through the sensitivity of crowns to mechanical damage during cutting. It appeared that crowns of the Peruvian cv. Tambo were strikingly less sensitive than those of the Californian cv. Moapa.

Potato yields of about $80 \mathrm{tha}^{-1}$ fresh tubers were obtained. The andigena cv. Revolución showed a high total dry matter growth rate of $270 \mathrm{~kg} \mathrm{ha}^{-1} \mathrm{~d}^{-1}$, but the duration of the linear growth stage was shorter than reported for optimum growth conditions in temperate regions (Bodlaender \& Algra, 1966). The Dutch cv. Désirée showed a $20 \%$ lower total dry matter growth rate than Revolución, but a similar tuber yield was obtained due to a higher harvest index. Split fertilizer application resulted in tissue nutrient concentrations lower than usually reported during most of the growing period, but the yield level and the concentration of $\mathrm{N}, \mathrm{P}$ and $\mathrm{K}$ in the tubers at the final harvest did not indicate any nutrient shortage. Results from a line-source sprinkler irrigation experiment indicated low transpiration coefficients, but also large water losses due to a low absorption capacity of the roots.

Both $\mathrm{C}_{4}$ crops, maize and Rhodes grass, reached high growth rates during summer, but much lower values in the other seasons, probably due to cold nights as shown by West (1973). Even so, annual Rhodes grass production in San Camilo (44 $\mathrm{t} \mathrm{ha}^{-1}$ ) was slightly higher than in Israel $\left(38 \mathrm{t} \mathrm{ha}^{-1}\right)$, as in the former region a longer period of favourable temperatures prevailed and also a longer continuation of the linear growth stage was observed. Maize was very sensitive to the mechanical impedance presented by the sandy pampa soils, especially without sub-soiling. However, on clay loam soils very high growth rates of $500 \mathrm{~kg} \mathrm{ha}^{-1} \mathrm{~d}^{-1}$ were reached. Hybrids originating from other regions and maize grown in a warmer environment at sea level showed slightly higher initial growth rates but at the expense of final yield. Both $\mathrm{C}_{4}$ crops required high $\mathrm{N}$ fertilization for optimum growth, although in Rhodes grass, a very efficient $\mathrm{N}$ recovery seems possible.

The simulation model BACROS (de Wit et al., 1978; Dayan et al., 1981) predicted the growth of maize and Rhodes grass during summer accurately, but the simulated values were too high for the other seasons as permanent damage to the assimilatory capacity due to low night temperatures was not taken into account in the model. The very high growth rates of maize on clay loam could not be simulated by the model either. Speculative model adaptations to account for these phenomena were possible, but further experimentation is needed to provide a physiological basis for such adaptations. 
The model PHOTON (de Wit et al., 1978) gave variable results with respect to calculated photosynthetis measurements in comparison with artificial swards of lucerne.

The model ARID CROP (van Keulen, 1975) was adapted to a lucerne cutting management model. The major changes were based on the observation during regrowth that a lucerne sward translocates a large part of its photosynthates to the root system. After cutting, root reserves are translocated to the stubble until the photosynthetic capacity is restored and simultaneously structural root material dies off. The simulated values for above- and below-ground production and reserve levels were close to the values measured in S. Camilo, at different cutting intervals varying from 21 to 53 days, but further experimentation is needed to investigate the estimated relations incorporated in the model.

Discussion. Around San Camilo, insuffient $N$ supply to non-leguminous crops is probably the main reason that actual production usually remains far below the potential. However, other crop-specific factors, such as low night temperatures (maize, Rhodes grass), mechanical soil resistance (maize) and cultivar characteristics like harvest index (lucerne, potato) are also important.

A drastic increase in water utilization efficiency (yield produced per unit irrigation water applied) can further be expected from improvement in the water supply. Actually, this is hampered by lack of effective monitoring of the water use by individual farmers and by the irregular water supply throughout the year.

Little direct impact from simulation studies on the project was obtained due to (i) difficulties in establishing close contacts with the modelling work in Wageningen due to the long distance and (ii) the relatively short duration of the project.

For predictions, simulation models are not very accurate if (as usual) for a particular environment no crop-specific data are available. Often, simplified calculation methods produce equally accurate predictions (Versteeg \& van Keulen, in prep.).

\section{References}

Alberda, Th., 1984. Production and water use of several food and fodder crops under irrigation in the desert area of south-western Peru. Agricultural Research Reports 928. Pudoc, Wageningen, $50 \mathrm{pp}$.

Bodlaender, K. B. A. \& S. Algra, 1966. Influence of the growth retardant B 995 on growth and yield of potatoes. European Potato Journal 9: 242-258.

Dayan, E., H. van Keulen \& A. Dovrat, 1981. Experimental evaluation of a crop growth simulation model. A case study with Rhodes grass. Agro-Ecosystems 7: 113-126.

Keulen, H. van, 1975. Simulation of water use and herbage growth in arid regions. Simulation Monographs. Pudoc, Wageningen, 184 pp.

Versteeg, M. N. \& H. van Keulen. Potential crop production predictions by some simple calculation methods, as compared to computer simulations. (Submitted to Agricultural Systems).

West, S. H., 1973. Carbohydrate metabolism and photosynthesis of tropical grasses subjected to low temperatures. In: R. D. Slatyer (Ed.), Plant response to climatic factors. Proceedings Uppsala Symposium, 1970. Unesco, Paris, pp. 165-168.

Wit, C. T. de et al., 1978. Simulation of assimilation, respiration and transpiration of crops. Simulation Monographs. Pudoc, Wageningen, 148 pp. 
Woodward, F. I. \& Sheehy, 1979. Microclimate, photosynthesis and growth of lucerne (Medicago sativa L.). II. Canopy structure and growth. Annals of Botany 44: 709-719.

This synopsis is based on a doctoral thesis, Agricultural University, Wageningen, 1985. $x+182$ pp., 89 figs., 26 tables, 269 refs. English, with Spanish and Dutch summaries.

Available as paper copy (order R028P, $f 30$ including postage) or on microfiche (order R028M, f 17.50) at: NARD, clo Pudoc, P.O. Box 4, 6700 AA Wageningen, Netherlands (telex 45015 blhwg nl).

\title{
Digestibility of plant fractions from different genotypes and the predictability of quality of forage maize in northwest Europe
}

P. C. Struik (Department of Field Crops and Grassland Science, Agricultural University, Haarweg 333, 6709 RZ Wageningen, Netherlands)

Received 20 December 1984; accepted 1 February 1985

\begin{abstract}
Differences in digestibility of plant parts from five genotypes of forage maize are described and related to the differences in whole-plant digestibility of crops, grown under different conditions. Plant parts differ greatly in digestibility, and their proportions of the dry matter of the total plant are variable, due to numerous physical, chemical, biological and genetic factors. Yet, whole-plant digestibility is fairly constant and predictable.
\end{abstract}

Key-words: forage maize, digestibility, genotype, brown-midrib, cell wall.

Introduction. Forage maize (Zea mays L.) is grown as feed for livestock reared for meat and milk production. The value of a maize crop is determined by factors affecting yield, preservation and feeding value. This paper is focused on feeding value estimated by digestibility in vitro and by cell-wall content.

Material and methods. Five genotypes of forage maize were sown on 26 April 1979 on a sandy soil at a density of 7 plants $\mathrm{m}^{-2}$. Twenty random plants were harvested on 11 October 1979 and separated into different fractions. Material was chopped, dried at $70^{\circ} \mathrm{C}$, weighed and ground. Chemical and biological analyses were carried out as described by Struik (1983a, b).

Growing conditions and procedures of sampling, handling and chemical analyses 